\title{
GSM Use Pattern for Information Dissemination and Evaluation of Income Level among Rural Dwellers in Uruan Local Government Area, Akwa Ibom State, Nigeria
}

\author{
${ }^{\text {a }}$ Michael E. Okon, ${ }^{\text {a }}$ Catherine I. Ogbodo

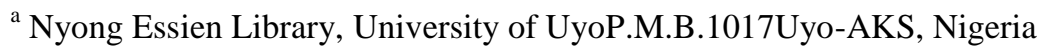

\begin{abstract}
The use of GSM phones in Nigeria started in 2001 after two communication giants MTN Nigeria and Econet (now Airtel Nigeria) were granted licenses by the Federal Government through the Nigerian Communication Commission (NCC). The study examined the GSM use pattern among five rural villages in Uruan Local Government Area of Akwa Ibom State in South - South zone of Nigeria. The study used the descriptive survey design. Researchers constructed questionnaire titled GSM use pattern and evaluation of income level among rural dwellers questionnaire "GUPEILRDQ" was administered on 500 respondents selected through simple random sampling from the five villages. Results indicate that the use of GSM phone among the people of this community is high. The pattern of use was found to decrease with age while men used GSM more than the women. Study also revealed that the use of GSM has positive impacts on the income levels and socio-economic lives of the people. Majority of the people relied on their friends, children, relatives, political and business associates to recharge their phones. Also most of the people were of the opinion that the introduction of GSM in the area is a blessing. A rural telephony project was embarked by the Federal Government of Nigeria but had been abandoned. Two major telephone operators MTN Nigeria and Airtel Nigeria have been embarking on rural telephone projects in the rural areas. The introduction of GSM in Nigeria has had great impact on the lives of the people.
\end{abstract}

Index Terms: GSM, use pattern, rural dwellers, Nigeria

(C) 2015 Published by MECS Publisher. Selection and/or peer review under responsibility of the Research Association of Modern Education and Computer Science.

\section{Introduction}

The Socio-economic development of a nation can be accelerated by improvements in the country's ICT infrastructure. This is as a result of the fact that Information and Communication Technologies (ICTs), if well 
harnessed can provide a platform for development across all sectors of the economy. ICTs are now making it possible for developing countries, like Nigeria to participate in the world economy in a manner that was not possible in the past. ICTs not only contribute to the development of commercial activities, health, security, education, commerce, agriculture and governance, but are also key enablers to broad-based social and economic development and of sustainable human development. Two reports by the World Bank (Information and Communication for Development Report, 2006) and the World Economic Forum (Global Technology Report 2005-2006), underline the fact that economic development depends on overall progress in the country's ICTs sector, without such progress, both the economy and private sector suffer.[1]

The mobile phone, an aspect of ICTs is viewed as an important tool of information dissemination and has become an integral part of the Nigerian society. Nigerians have continuously increased the use of mobile phones instead of the fixed line telephone as a means disseminating information to family members, friends, business associates and colleagues at work. It has also become a major source of income generation for the entire populace irrespective of where one is located. The Global System Mobile of communication popularly called the GSM came into existence in Nigeria during the democratic regime of Olusegun Obasanjo in 2001.

This was as a result of the liberalization policy in the telecommunication sub-sector of the Nigerian economy. The period 1992 to 1999 were years of liberalization, during these years, the Nigerian Government undertook partial liberalization of the Nigerian telecommunication industry through a decree which established the Nigerian Communication Commission (NCC),Decree 75 of 1992[2]. The liberalization of the telecommunication sector brought an exponential growth in the industry. Using this as an index and empowered by the decree, the NCC conducted an open auction for GSM licenses. Two companies, MTN Nigeria and Econet Wireless Nigeria (now Airtel) who won the bid and were able to pay the mandatory amount within the stipulated dateline were granted licenses

Before the advent of GSM in Nigeria, the citizens had a hell of time communicating with one another as a result of epileptic services and bad management of the Nigerian Telecommunication Limited, NITEL which was the only telephone operator at that time. Endless queues became the order of the day at various NITEL centres, while corrupt practices by NITEL staff thrived at the expense of quality services for which NITEL was established to offer Nigerians. Thus, the introduction of GSM in Nigeria brought a great relief to majority of the populace. Since the advent of the GSM communication in Nigeria, information dissemination in form of voice and data has been made easy.

At independence in 1960, with a population of about 45 million people, Nigeria had about 18, 724 lines for use. This translated to a teledensity of a telephone line to 2403 people [3]. Major improvements have been recorded after GSM communication became operational in Nigeria. Available statistics indicated that, the teledensity increased from $86.25 \%$ in May 2013 to $93.70 \%$ in May 2014.Also, tele density rose slightly from 80.85 percent in December 2012 to 81.78 percent at the end of January 2013, while telecoms subscriber base in the country rose to $114.1 \mathrm{~m}$ at the end of January 2013[4]. It is believed that the GSM industry in Nigeria would continue to witness positive growth in the years ahead. As observed by the minister of communication, Mrs. O. Johnson the teledensity in Nigeria would likely reach 98 percent by 2015[5] Tele density is the percentage of connected lines in relation to the population in a given period of time; and its growth is proportional to the growth in telephone subscribers' base[6].

\section{Statement of the Problem}

Before the advent of GSM in Nigeria in 2001, information dissemination among the rural dwellers used to be in form of verbal messages through an informant or letter sent by a carrier through road transport network or by post through NIPOST facilities. Although there were few courier companies, service delivery through this means were restricted to the cities and were very expensive for the common man. NIPOST, which could reach all rural areas, soon became non-functional at a time and more so messages could take months before it gets to the recipient and in some cases the information could become stale. NITEL, the only telephone operator at that 
time apart from rendering epileptic services was not within the reach of the common Nigerian. In fact, individual in the cities with robust financial background could not secure telephone lines long after having paid for such lines for months.

Information dissemination within the rural communities was a major challenge and in most cases, information was only one way with no feedback. Similarly, before the advent of GSM in Nigeria, means of generating income within the rural areas were confined to trading, farming and fishing. The advent of GSM opened a new chapter in income generation as several businesses in GSM emerged. The introduction of GSM to reach the rural areas in Nigeria was a major relief. Over the years, some improvements have been recorded in the GSM sector and it has become imperative to examine if these improvements have yielded positive impacts on the lives of the rural dwellers, in terms of information dissemination and income generation.

\section{Objectives of the study}

Specially, the study sought to:-

i Determine the frequency of usage of mobile phones for information dissemination by rural dwellers in Uruan local government area

ii Determine if the use of mobile phone has any positive impact on income level of the dwellers of this rural area

iii Determine if the use of mobile phones has any impact on the socio-economic lives of the people in the rural areas.

iv Determine whether there exists a relationship between age, gender with the use of mobile phone

$\mathrm{v}$ To find out what challenges if any are experienced by the rural dwellers in the course of using GSM phones

\section{Research Questions}

The following research questions were formulated.

1. How often do owners of GSM phones use its facilities to disseminate information

2. Do owners of GSM phones have the requisite competencies to use their phones to access and retrieve information?

3. Does the use of GSM have any positive impact on the income level and the socio-economic lives of the people?

4. Is there any relationship which exists between age and gender with the use of GSM phones?

5. Are there problems encountered by the rural dwellers in the course of using GSM?

\section{Research methodology}

\section{A. Area of Study}

Uruan Local Government Area is one of the Local Government Areas in Akwa Ibom State created on $6^{\text {th }}$ May 1989. It occupies an expanse of land about 403.0389 kilometres and is bounded on the East by Cross River State, Figure 1. Map of Akwa Ibom state showing area of study (Uruan) Local Government Area. 


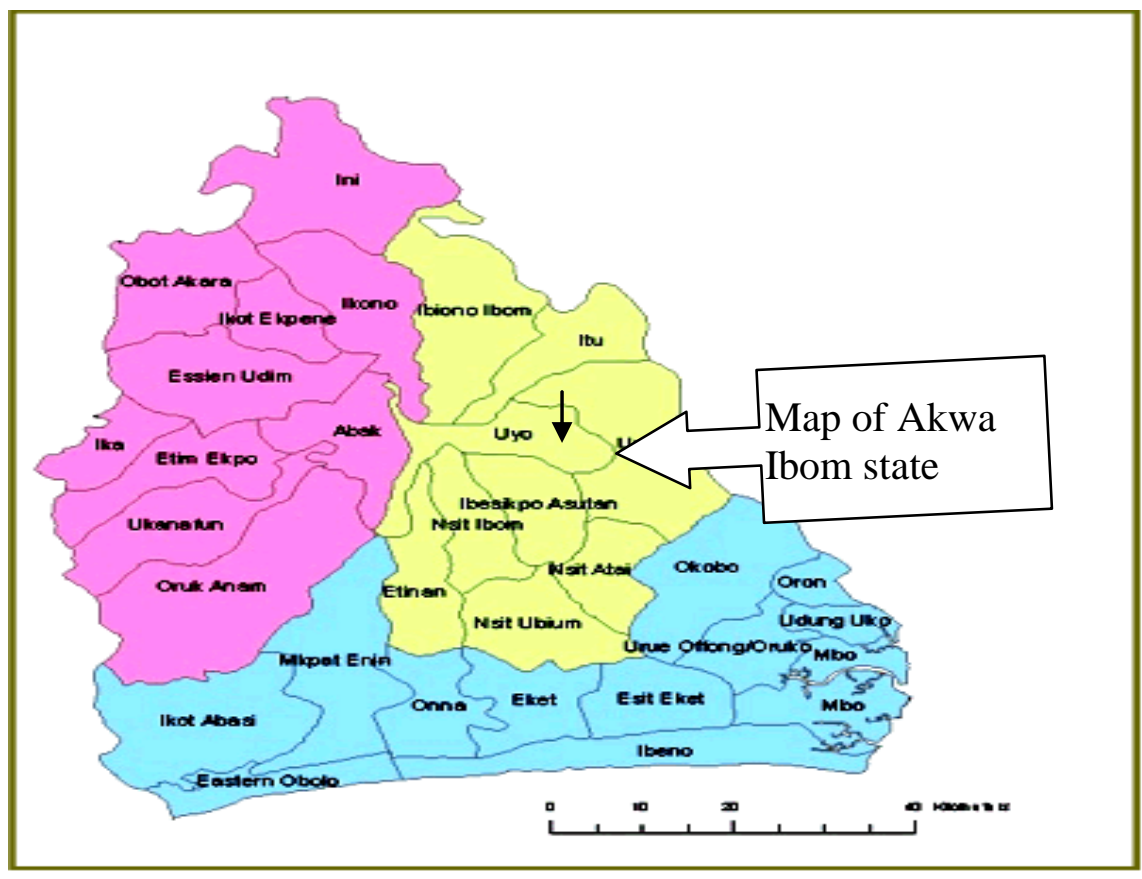

Fig.1.Map of Akwa Ibom State, Nigeria Showing Uruan Local Government Area

On the North by Itu Local Government Area, on the West by Ekpe Atai and Uyo local government areas respectively. The vegetation is green all the year around and the area lies in the rain forest belt. There are creeks, rivulets, streams and extensive arable land [7].

\section{B. Research design}

The descriptive survey design was used for the study. Researchers constructed Questionnaire titled "GUPIDEILRDQ" was administered to the respondents. The questionnaire consisted of two sections A and B. Section A was made up of demographic information while Section B consisted of items on questions related to the use of GSM. The questionnaire was made in simple English to the understanding of the respondents. Items on the questionnaire were interpreted in the local language to some of the respondents who could not understand the items very well. The researchers also personally assisted the respondents to fill the questionnaire. Interviews were adopted where it became necessary. All completed questionnaires were collated and the responses put into a table. Responses were analyzed using simple percentages.

\section{Population of the Study}

The populations studied were the rural dwellers of southern uruan communities in Uruan Local Government Area. The villages are Nung Ikono Ufok, Nung Ikono Obio, Ikot Akan, Use Uruan and Ikot Akpa Ekang. The population comprised of political class, religious leaders, market women, students and traditional leaders (family heads and chiefs) selected from the five villages. The students comprised those living within the vicinity and going to post- primary schools and those on holidays. The population comprising a total of five hundred persons (100 per village and-20 from each group) was selected through simple random sampling. 
Table 1. Respondents by Sex and Marital Status

\begin{tabular}{cccccc}
\hline Sex & Frequency & Percentage & Marital Status & Frequency & Percentage \\
\hline Male & 300 & 60 & married & 180 & 36 \\
Female & 200 & 40 & single & 300 & 60 \\
& & & Divorced/ Separated & 20 & 4 \\
Total & 500 & 100 & & 500 & 100 \\
\hline
\end{tabular}

Source: Field Survey 2014

Table 1 shows respondents by sex and marital status .300 or 60 percent represented male while 200 or 40 percent were female. One hundred and eighty (180) or thirty six (36) percent were married while three hundred or sixty (60) percent were single and twenty (20) or four (4) percent were divorced or separated.

Table 2. Respondents by Age and Educational Qualification

\begin{tabular}{cccccc}
\hline Age & Frequency & Percentage & Qualification & Frequency & Percentage \\
\hline Under 20 & 140 & 28 & B.sc/M.sc/PH.D & 10 & 2 \\
$21-30$ & 160 & 32 & N.C.E/Diploma & 30 & 6 \\
$31-40$ & 150 & 30 & Teachers grade 2 & 10 & 2 \\
$41-50$ & 30 & 6 & FSLC & 250 & 200 \\
51 -above & 20 & 4 & No qualification & $\mathbf{5 0 0}$ & 40 \\
\hline Total & $\mathbf{5 0 0}$ & $\mathbf{1 0 0}$ & & $\mathbf{1 0 0}$ \\
\hline
\end{tabular}

Source: Field Survey 2014

Table 2 shows respondents by age and educational qualification. 140 or 28 percent were under the age of 20 , 160 or32 percent were made up of those between the ages of 21-30, 150 representing 30 percent were those of ages31-40,30 respondents or 6 percent were those of ages 41-50 while those of ages 50 and above were 20 representing 4 percent. For educational qualification, Ten (10) persons representing 2 percent had bachelors and higher degrees, thirty (30) or six (6) percent were holders of diploma, NCE or Higher National Diploma, ten (10) or two (2) percent were holders of Teachers grade 2. Two hundred and fifty (250) or fifty (50) percent had First School Leaving Certificate (FSLC) whereas those with no qualification at all represented two hundred or forty (40) percent.

\section{Results}

Answer to Research Question 1

Table 3. How often do you use your GSM to Make/Receive Calls?

\begin{tabular}{ccccc}
\hline Groups & $\begin{array}{c}\text { Very } \\
\text { Often }\end{array}$ & Often & Averagely & Occasionally \\
\hline Political groups & Yes & - & - & - \\
Religious leaders & - & Yes & - & - \\
Traditional leaders & - & Yes & - & - \\
Market women/business Persons & Yes & - & - & - \\
Students & Yes & - & - \\
\hline
\end{tabular}

Source: Field Survey 2014 
Table 3 indicates respondents' response to how often they make or receive calls. The political groups, market women/business persons and students were found to make more calls and receive same while traditional and religious leaders were found to also make calls but not as often as the other three groups.

Answer to Research Question 2: Do owners of GSM have the requisite competencies to use their phones?

Table 4. Are you able to Use the Different Functions on your GSM Phone?

\begin{tabular}{ccccc}
\hline Functions & V.W/W & Percentage & N.V.W/D.K & Percentage \\
\hline Call function & 340 & 68 & 160 & 32 \\
Messaging Function & 320 & 64 & 280 & 36 \\
Log function & 220 & 44 & 320 & 56 \\
Setting Function & 180 & 36 & 380 & 76 \\
Gallery Function & 120 & 24 & 150 & 30 \\
Contact Function & 350 & 70 & 320 & 64 \\
Application Function & 180 & 36 & 320 & 64 \\
Media Function & 180 & 36 & 400 & 80 \\
Web function & 100 & 20 & 280 & 56 \\
Organizer Function & 220 & 44 & 2790 & 56 \\
Total & 2210 & 44 & & \\
\hline
\end{tabular}

Source: Field Survey 2014 V.W=very well, W=well, N.V.W=not very well, D.K=don’t know

Table 4 shows respondents response of their competence in using different GSM functions. Three hundred and forty (340) or sixty eight (68) percent were familiar with how to use the call functions, three hundred and twenty (320) or sixty four (64) percent were familiar with how to use the SMS functions while three hundred and fifty (350) representing seventy (70) percent could use the contact functions. These are the three basic functions related to disseminating information and sending messages.

Table 5 Answer to Research Question 3: Does the use of GSM improve your income level?

Table 5. Indicates Income Level of Respondents using GSM Mobile Phone

\begin{tabular}{|c|c|c|c|c|c|}
\hline $\mathbf{A}$ & Frequency & Percentage & B & Frequency & Percentage \\
\hline $2500-3000$ & 100 & 20 & above 2000 & 60 & 12 \\
\hline 2000-2004 & 120 & 24 & $1500-1900$ & 80 & 16 \\
\hline $1500-1900$ & 80 & 16 & $1000-1400$ & 60 & 12 \\
\hline $1000-1400$ & 80 & 16 & $500-900$ & 100 & 20 \\
\hline Below 1000 & 40 & 8 & $200-400$ & 120 & 24 \\
\hline 0 & 80 & 16 & below 200 & 80 & 16 \\
\hline Total & 500 & 100 & & 500 & 100 \\
\hline
\end{tabular}

$\mathrm{A}=$ total income $(\mathrm{N})$ earned in a month using GSM, $\mathrm{B}=$ total expenditure $(\mathrm{N})$ in a month from GSM use

Table 5 indicates that 100 persons or 20 percent of respondents make an income of between 2500- 3000 naira monthly while 60 respondents or 12 percent spend between 2000-2400 naira monthly. 80 persons representing 16 percent make an income of between 1500- 1900 naira monthly, while 80 persons or 16 percent spend between 2000-2400 naira monthly. 80 and 60 respondents representing 16 and 12 percent make between 1000-1400naira and spend between 1500-1900 naira monthly respectively. Forty(40) or eight percent make below a thousand naira monthly while eighty(80) respondents or sixteen(16) percent do not make 
any income at all from the use of GSM. One hundred (100) respondents or twenty (20) percent spend between 1000-1400 naira monthly, one hundred and twenty or 24 percent of respondents agreed they spend between 500-900 naira monthly and eighty (80) or sixteen (16) percent of respondents spend below 500 naira monthly.

Table 6. Sources of Income from the Use of GSM Phone

\begin{tabular}{ccc}
\hline Sources & Frequency & Percentage \\
\hline $\begin{array}{c}\text { Sale of recharge cards } \\
\text { Repairs/maintenance and Sale of GSM } \\
\text { phone/accessories }\end{array}$ & 50 & 11.9 \\
$\begin{array}{c}\text { Credit transfer from friends/ } \\
\text { Relatives/business and } \\
\text { Political associates }\end{array}$ & 10 & 71.4 \\
$\begin{array}{c}\text { Charging of phones with the } \\
\text { Use of generators }\end{array}$ & 300 & 14.3 \\
Total & 60 & \\
\hline
\end{tabular}

Results as indicated on table 6 show that majority of respondents (300) or 71.4 percent obtain income from use of GSM through credit transfer from friends, relatives, business and political associates. 60 respondents or 14.3 percent obtain income from use of GSM through charging of phones using generating sets. 50 persons representing 11.9 percent obtain income from use of GSM through the sale of recharge cards, while 10 persons or 2.4 percent obtain income from use of GSM through maintenance, repair and sale of GSM phones/accessories

Answer to research question 3: impact on socio-economic lives of the people: Respondents were asked if GSM has impacted on their lives.

Table 7. Impact of GSM on the Socio- Economic Lives of the People

\begin{tabular}{ccc}
\hline Benefits & Frequency & Percentage \\
\hline GSM serves as watch & 480 & 96 \\
I use GSM to listen to radio/news & 300 & 70 \\
It helps reduce time of traveling & 350 & 100 \\
I call my family, friends regularly \\
receives calls & 500 & 60 \\
I use GSM to earn money through & 300 & 4 \\
Making calls and getting free cards & & \\
From friends and relatives & 20 & 12 \\
I use GSM to call my customers \\
When my products arrive \\
I sue GSM to browse the net \\
With GSM, I have all information I \\
Need at my disposal \\
GSM is very useful
\end{tabular}


Table 7 indicates the benefits of GSM to the respondents: three hundred (300) or sixty (60) percent said their mobile phones enable them to listen to news on radio, three hundred and fifty or seventy (70) percent said it helps them to reduce the time of travelling. This is corroborated by [8] who noted that the introduction of mobile telecoms has the potential of reducing the cost of business and increasing output. Three hundred or sixty percent said they are able to use their phones to obtain recharge cards from friends and family members. All five hundred respondents agreed that the introduction of GSM was very a big blessing to them.

Answer to Research Question 4: Respondents were asked by age how often they use GSM phones?

Table 8. Frequency Percentage Frequency Percentage

\begin{tabular}{|c|c|c|c|c|}
\hline Age & Very often/often & Percentage & $\begin{array}{l}\text { Not very often } \\
\text { /occasionally }\end{array}$ & Percentage \\
\hline Under 20 & 100 & 71.4 & 40 & 28.6 \\
\hline $21-30$ & 120 & 75.0 & 40 & 25.0 \\
\hline $31-40$ & 120 & 66.7 & 50 & 33.3 \\
\hline $41-50$ & 18 & 60.0 & 12 & 40.0 \\
\hline 51- Above & 8 & 40.0 & 12 & 60.0 \\
\hline
\end{tabular}

Source: Field Survey 2014

The results indicated those within the age brackets( under 20) use phone very often(71.4) percent, those of age brackets(21-30) use GSM phone most(75.0), those of age brackets(31-40) 66.7 percent, age brackets(41-50) 60.0 percent while those of ages (41-50) forty percent. In general those of lower ages tend to use the phones more than those of older ages. This is in tandem with the studies of [8] and [9] who noted that there was a rapid use of mobile phones among these groups because pre-paid subscription and device subsidy eliminated economic barriers to adoption. Thus teenagers were also encouraged through this opportunity to build solidarity and share experiences amongst friends and appreciated its symbolic value. A careful examination of these and other studies provide an explanation into mobile phone use that has been adopted to suit these age groups [10]. As observed by [11] there are variations in contact management between teenagers and adults. Teenagers they argue that 25-35 olds are different to 16-18s and 50-60s in that they do more work integrating contact details obtained with a wide range of media (face-to face, via the telephone, e-mail, and SMS). Teenagers they argue had a greater number of contacts, and tended to use the mobile phone to store details.[12] offers another explanation for reduced mobile phone use in older adults concerns differences in life situations. Younger adults, one imagines, often lead unstructured lives - they are single, attending college and living in temporary accommodation. Older adults, in contrast, have an established home and family, and seek to balance commitments to work and family. Differences in life situation are less comforting for the mobile industry, because the imply that high rates of mobile phone use throughout adulthood are not inevitable - the benefits that users perceive as teenagers will not necessarily be perceived when they are adults, and habitual use will evolve away from the mobile phone, should it cease to benefit users' changing situations

Table 9. Respondents Were Asked By Sex How Often They Use GSM Phones.

\begin{tabular}{ccccc}
\hline Sex & $\begin{array}{c}\text { Very often/ } \\
\text { Often }\end{array}$ & Percentage & $\begin{array}{c}\text { Not very/ } \\
\text { occasionally }\end{array}$ & Percentage \\
\hline Male & 250 & 83.3 & 50 & 16.7 \\
Female & 120 & 60.0 & 80 & 40.0 \\
\hline
\end{tabular}

Source: Field survey 2014 
Table 10 indicates respondents' response in terms of their sex. Results indicated that two hundred and fifty or 83.3 percent of male use the mobile phones very often to make or receive calls while 50 or 16.7 percent said they use the mobile phones occasionally. Female respondents of a total of 120 or 60 percent use the mobile phones very often to make or receive calls while 80 or 40 percent of female respondents said they use their mobile phones occasionally. By implication, results indicate that men use mobile phones more than women. This could be as a result that more men who happen to fall into the political, religious and traditional leaders use their phones very often due to their nature of job. The researchers are of the opinion that sex or gender variable alone may not be used to determine frequency of usage.[9] have noted in their study of GSM use by university students in Malaysia that gender has a little or no effect on the rate of calls received per day.

Table 10. Answer to Research Question 5: Respondents were Asked if they have any Difficulties using GSM

\begin{tabular}{|c|c|c|}
\hline Difficulties & Frequency & Percentage \\
\hline I experience network problems & 200 & 40 \\
\hline I do not have money to recharge My phone most times & 100 & 20 \\
\hline $\begin{array}{c}\text { My children/grand children Plays with my phone whenever I } \\
\text { Forget to put it back in my bag }\end{array}$ & 50 & 10 \\
\hline $\begin{array}{c}\text { I have difficulties charging my phone because of lack of } \\
\text { Supply of electricity }\end{array}$ & 150 & 30 \\
\hline
\end{tabular}

Table 10shows the difficulties encountered by respondents in the course of using GSM phones. Two hundred representing forty (40) percent said they usually have network problem that is unable to connect while trying to make calls. One hundred (100) or twenty (20) percent said they usually have problems affording money to buy recharge cards, Fifty persons (50) representing (10) percent said their children or grand children plays and fiddle with their phone if they forget to put it back in their bags after use while one hundred and fifty (50) or thirty (30) percent said they usually have problems charging their phones because of lack of constant power supply.

\section{Findings and Discussions}

Findings revealed that rural dwellers in uruan local government area of Akwa Ibom State are very happy with the introduction of GSM communication in the area. Majority of the respondents use GSM maximally and it has positive impact on their income level. Most respondents also agreed that GSM communication has been a great blessing to them because they are now able to do most of the things they could not do in the past by using GSM phones. Older respondents who have children and grandchildren in different parts of the country and outside the country are so excited with this technology. They confessed that with GSM their children and grandchildren call them very often to find out what was happening at home. They also use this medium to inform them of money transferred to them at various times, send recharge cards to them for use

Some groups of respondents like the political class, market women and students were found to have a very high level of use of their GSM phones compared to the religious and traditional rulers. The reason is that the earlier groups constantly have to reach out to their peers in the cities or within the environs for information on what makes the news, business related information.

Majority of the respondents use their phones to receive calls and makes calls occasionally.

Majority of respondents, were familiar with the different functions on their phones. They use their phones maximally even though this was restricted to mostly making and answering calls as well as sending text messages.

There was a relationship which exists in the use of phone by respondents. Usage tends to decrease with 
increase in age. The younger generation was found to use GSM more than the older generation. Also the use of GSM among respondents varied with respect to gender. Male were found to use the phones more than the females.

In general, the level of use of GSM among respondents was found to be high.

Problems encountered by respondents using GSM phones

Lack of knowledge on how to use the different functions of GSM phones

- Inability of respondents to always have the resources to buy recharge cards

- Lack of regular power supply to always charge their phones

- Problem of network availability

- Lack of adequate provision of telecommunication and related infrastructure

- Rural telephony project in Nigeria

\section{National Rural Telephony Project}

Rural telephony project had been embarked upon in Nigeria by the Federal Government. It was initiated by President Olusegun Obasanjo and was designed to take telephone to all nooks and crannies of Nigeria aimed at reducing rural-urban migration. To achieve this, the Federal Government through a US200m dollar concessionary loan from China awarded the first phase of the project in 2001 meant to cover 217 rural villages to two Chinese companies.

- Alcatel Shanghai Bell (ASB) and ZTE was meant to provide fixed wired ling while ZTE was to provide fixed wirelesses - Code Division Multiple Access (CDMA) The country was divided into seven zones

- Abuja, Bauchi, Enugu, Kaduna, Kano Ibadan and Port Harcourt and each zone consisted of six states, except Kano which had four states.

- Unfortunately, the project has been stalled and the prospect of continuation of the project for now is uncertain.

\section{MTN Rural Telephony Development}

MTN Nigeria, one of the major telecommunication operators in the country had taken a hold step towards making mobile telephone accessible to the rural populace in Nigeria with the erection of 350 base stations across the country. The project cost 40m dollars deal with Hauwai Technologies was launched in October 21, 2010 is meant to cover 850 rural villages in Nigeria.[14]

\section{Zain'S Rose Project}

The Zain Rose project by Airtel is another effort at making mobile telephony within the reach of the rural communities in Nigeria. Airtel has announced an empowerment initiative that focuses on creating awareness for ICT use and uptake across the country [15]. The programme tagged: Boost ICT Usage in Rural areas" is designed to help consumers living or visiting the designated areas in the rural communities to have first-hand experience of the company's unequalled data services with no financial implications to the consumers. The Airtel ICT project will cover rural areas in Ebonyi, Enugu, Benue, Anambra, Delta, Edo, Abia,Bayelsa, Akwa Ibom, Cross River Lagos, Rivers, Ekiti, Oyo, Ondo, Osun, Kwara,Imo, and the Federal Capital Territory(FCT).

\section{Benefits of Gsm to the Nigerian Economy}


- Creation of employment

- Contribute to rural development

- Enable efficient means of information dissemination

- Promote international trade

- Facilitates business and other economic transaction

- Enhances security system

- Major source of information through the internet

- Reduces road congestion

- Reduces risk and accidents on road

- Can be useful for use at emergency situations like fire disasters, armed robbery, and violence.

- Generation of income to individuals

\section{Conclusion}

The use of the GSM mobile has come to stay in Nigeria and has become a big blessing. Information dissemination in the form of voice and data is now used to communicate from one person to another. GSM has reduced the time and cost of doing business as it is possible to call and confirm any information before embarking on any trip. It has also brought a major relief to dwellers of the rural areas who before will spend weeks or months to reach out to their loved ones in the towns and cities. Indeed, GSM has made it possible to reach every nooks and cranes in Nigeria.

\section{References}

[1] Isiguzo, I.: The Impact of Mobile Services in Nigeria How mobile Technologies are transforming Economic and Social Activities. Pyramid Research. 2010.

[2] Ajayi et al: A century of Telecommunication Development in Nigeria - What next? Retrieved from http://file./f.telecom/Nigeria.htm.p.7.2008.

[3] Ademola O. etal: The Introduction of GSM Services in Anyigba Community and its impact on student's expenditure pattern. Global Journal of Management and Business Research Finance.2013 13(8) 72-81.

[4] Okwuke, E: Nigeria's teledensity hits $81.78 \%$ as active line peaks at $114.1 \mathrm{~m}$ DailyIndependentdailyIndependentnig.com/2013/03/nigerias_teledensityhits81.78activelinepeaksat114. 1, 2014 Retrieved26thAug.2014.

[5] Okonji, E. Nigerias Mobile Teledensity predicted to reach $98 \%$ in 2013. Retrieved from www.thisdaylive.com/articles/Nigeria_mobile teledensity predicted_to _reach_98in2015/151394/.2014.

[6] Amkpa, S. A. and Okon, H. I.: Assessment of Students' GMS phone use pattern at the Faculty of Education, University of Uyo. The Information Technologist 2006. 3(1) 36-42.

[7] Odioh, N. Akwa Ibom State on the move: brief history of Local Government. Ministry of Information and Culture. Uyo 1989

[8] Adebayo, F.: Seven years of telecom revolution- the fun and fury. This is how it all began. Tell magazine of Nigeria 2008.

[9] Ling, R. The mobile connection: The cell phone's impact on society" Morgan Kaufmann, New York.2004

[10] Ajagbe, A.M.et al: The use of Global system Mobile (GSM) among university students in Malaysia. International Journal of Innovation management and Technology2011 2(6)512-513.

[11] Berg, S. Talyor A.S. and Harper, R.: Mobile phones for the next generation: device designs for teenagers. In Proceedings of CHI (Ft. Lauderdale, FL USA). ACM Press Boston, 2003 433-440. 
[12] Smith, H., Rogers, R. and Brady, M.: Managing one's social network: Does age make a difference? IFIP Proceedings of Interact (Zurich, Switzerland, Sept. 2003), 551-558.

[13] Colbert, M.: Younger and older adults use of mobile phones for rendezvousing. 2004.

[14] Oketola, D. MTN boosts rural Telephony with 340 base station. The Punch Retrieved from www.punch.ing.com/business/Technology/mtn_boosts_rural_telephony with 340 base stations.2014.

[15] Adepetun, A.: Airtel takes ICT to rural communities. The Guardian Newspapers. Aug. 28. 2014 P. 25.

\section{Author's Profiles}

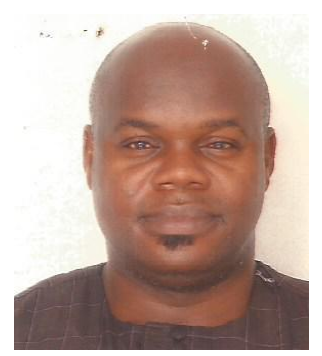

Michael Okon (born February 20, 1964) holds a Bachelors of Science degree in Pure/Applied Chemistry and Masters of Library and information science degree from the Universities of Calabar and Ibadan, Nigeria respectively. Okon is a former President of the staff multipurpose cooperative society of the University of Uyo, and the founding chairman UNIUYO microfinance bank limited. A staff of the University Library, he is about finishing his $\mathrm{PhD}$ in information science at the University of Uyo, Nigeria.

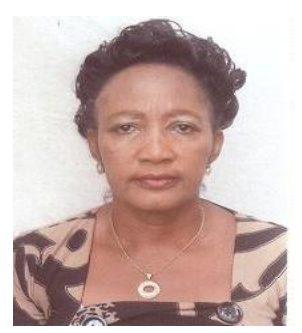

Catherine Ogbodo (born February8, 1962) holds Bachelors and masters degree in Library and Information from the Universities of Nigeria, Nsukka and Uyo. A staff of the University of Uyo Library, she is the Head of Division, Resource Development Division (RDD) of the library.

How to cite this paper: Michael E. Okon, Catherine I. Ogbodo,"GSM Use Pattern for Information Dissemination and Evaluation of Income Level among Rural Dwellers in Uruan Local Government Area, Akwa Ibom State, Nigeria", IJEME, vol.5, no.4, pp.1-12, 2015.DOI: 10.5815/ijeme.2015.04.01 